\title{
ANTIOXYDANT ACTIVITY OF ANT NEST PLANTS (HYDNOPHYTUM FORMICARUM AND HYDNOPHYTUM PAPUANUM) IN PAPUA
}

\author{
Sarce Makaba \\ Faculty of Public Health, Cenderawasih University
}

\begin{abstract}
Background: Ant nest plants are common in Papua and have been used by people to cure various diseases, particularly degenerative diseases. Antioxydant in these plants has an important role to maintain good health since it can capture free radical molecules and reactive oxygen species (ROS). As such, it can inhibit oxydative reaction as a cause of degenerative diseases. The purpose of this study was to examine antioxydant activity of ant nest plant (Hydnophytum formicarum and Hydnophytum papuanum) in Papua.

Subjects and Method: This was a laboratory experiment. Antioxydant activity was tested using 1.1-difenil-2-pikrilhidrazil ( $\alpha, \alpha$-difenil- $\beta$ pikrilhidrazil) or DPPH.
\end{abstract}

Results: Hydnophytum formicarum showed oxydant activity with $\mathrm{IC}_{50}=$ $7.03 \mu \mathrm{g} / \mathrm{mL}$. Hydnophytum papuanum showed oxydant activity with $\mathrm{IC}_{50}=$ $6.19 \mu \mathrm{g} / \mathrm{mL}$.

Conclusion: Hydnophytum formicarum and Hydnophytum papuanum show oxydant activity.

Keywords: antioxydant activity, Hydnophytum formicarum, Hydnophytum papuanum

Correspondence: Sarce Makaba. Faculty of Public Health, Cenderawasih University. Email: sarcemakaba@gmail.com. Mobile: +6282199354082. 